\title{
Evaluation of Pseudophakic Patients with Epiretinal Membrane: Our Experience
}

\author{
Kliniğimize Başvuran Psödofakik Epiretinal Membranlı Olguların Değerlendirilmesi
}

\author{
(D) Mustafa Suat Alıkma, (D) Erkan Ünsal \\ İstanbul Training and Research Hospital, Clinic of Ophthalmology, istanbul, Turkey
}

\begin{abstract}
Introduction: The aim of this study was to evaluate the clinical features of pseudophakic patients with idiopathic epiretinal membrane (ERM) and to compare the optical coherence tomography (OCT) macular characteristics of the eye with ERM with the normal eye.

Methods: Patients with bilateral pseudophakic eyes and ERM in one eye who were admitted to our clinic between 2017 and 2018 were evaluated according to gender, age, visual acuity and OCT findings and the relationship between these findings were evaluated statistically.

Results: Eighty-two eyes of 41 patients with a mean age of $71.4 \pm 6.4$ years (range: $60-86$ ) who were admitted to our clinic between 2017 and 2018 were included in the study. All eyes were pseudopkahic. The patients with systemic and ocular disease history were not excluded. Nineteen (46\%) patients were female and 22 (54\%) were male. ERM was on the right side in 21 (51\%) eyes and on the left side in 20 (49\%) eyes. The mean visual acuity of the eyes with ERM was $0.35 \pm 0.24$ (0.11.0) LogMAR. The mean central macular thickness of the eyes with ERM was $355.4 \pm 75.4$ (234-554) microns. Regarding the parafoveal region (1-3 $\mathrm{mm}$ ), the superior quadrant thickness was $371.4 \pm 60.3$ (range: 287-558) microns, nasal quadrant thickness was $371 \pm 52.5$ (range: 311-549) microns, inferior quadrant thickness was $365.6 \pm 44.3$ (range: $307-494$ ) micron and temporal quadrant thickness was $365.1 \pm 52.2$ (range: 280-510) micron. In the eyes with ERM, the macular volume was $11.3 \pm 1.1(9.7-15) \mathrm{mm}^{3}$ by OCT. There was a statistically significant difference between eyes with and without ERM in terms of central macular thickness, macular volume, superior, temporal, inferior and nasal quadrant thicknesses of parafoveal region $(1-3 \mathrm{~mm})(\mathrm{p}<0.05)$.
\end{abstract}

Conclusion: ERM is a disease related to advanced age. Since the disease occurs at the vitreoretinal interface, it causes some changes in optic cohorence tomography.

Keywords: Epiretinal membrane, vitreoretinal interface, vision loss

\section{öz}

Amaç: Kliniğimize başvuran idiyopatik psödofakik epiretinal membranlı (ERM) olguların klinik muayene bulguları ve optik koherens tomografi (OKT) ile değerlendirilen maküla özellikleri ile aynı olguların normal gözleri karşılaştırılarak değerlendirme amaçlanmıştır

Yöntemler: 2017 ve 2018 yılları içerisinde kliniğimize başvuran, bilateral psödofakik ve tek gözlerinde ERM bulunan olgular cinsiyet, yaş, görme keskinliği ve OKT bulgularına göre değerlendirilerek bu bulgular arasındaki ilişki istatistiksel açıdan değerlendirildi.

Bulgular: 2017 ve 2018 yılları içerisinde kliniğimize başvuran yaş ortalaması $71,4 \pm 6,4$ yıl (60-86 arasında) olarak tespit edilen 41 hastanın 82 gözü çalıșmaya dahil edildi. Çalıșmaya idiyopatik ERM'si olan psödofakik olgular alındı. Sistemik ve oküler hastalık anamnezi olan olgular çalıșma kapsamına alınmadı. Hastaların 19'u (\%46) kadın ve 22'si (\%54) erkek olarak tespit edildi. Çalışmada ERM bulunan gözlerden 21'i (\%51) sağ göz ve 20'si (\%49) sol göz olarak tespit edildi. Olguların görme keskinlikleri ortalama olarak 0,35 $\pm 0,24$ (0,1-1,0 arasında) LogMAR olarak tespit edildi. ERM bulunan

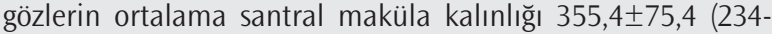
554 arasında) mikron, parafoveal bölgede $1-3 \mathrm{~mm}$ mesafedeki dairesel alanda superior kadran kalınlığı 371,4 460,3 (287-558

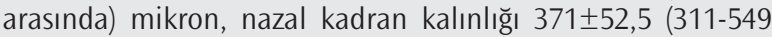
arasında) mikron, inferior kadran kalınlığı 365,6 $\pm 44,3$ (307-494

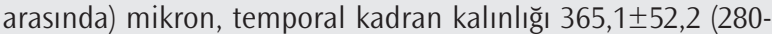
510 arasında) mikron olarak tespit edildi. ERM bulunan gözlerde

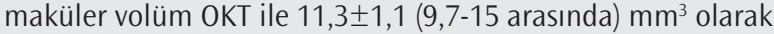
tespit edildi. ERM bulunan ve bulunmayan gözlerdeki santral maküla kalınlıkları, maküler volüm, parafoveal bölgede 1-3 $\mathrm{mm}$ mesafedeki dairesel alanda superior, temporal, inferior ve nazal kadran kalınlıkları arasında istatistiksel olarak anlamlı fark saptandı $(p<0,05)$.

Sonuç: ERM ileri yaş ile ilgili bir hastalıktır. Hastalık vitreoretinal ara yüzeyde oluștuğu için OKT'de bazı değişikliklere yol açar.

Anahtar Kelimeler: Epiretinal membran, vitreoretinal ara yüzey, görme azlığı 


\section{Introduction}

Epiretinal membrane (ERM) is a vitreoretinal interface disease that leads to a decrease in visual acuity, macropia, micropsy and metamorphopsia symptoms. These symptoms have been associated with macular surface deterioration and macular thickness increase $(1,2)$. Diagnosis is made clinically and by means of optical coherence tomography $(\mathrm{OCT})(3,4)$. ERM is formed on the internal limiting membrane (ILM) and has a fibrocellular structure (5). ERM diagnosis and classification is based on clinical findings (6).

ERM is etiologically classified as primary and secondary ERM (3). ERM without pathological ophthalmic examination other than posterior vitreous detachment is called primary idiopathic ERM $(7,8)$. Secondary ERM can occur as a result of many etiological factors such as ocular trauma, cryopexy, intraocular surgeries and vascular pathologies related to the retinal artery and veins (4). Although the disease is generally benign, it may cause functional defects by causing shrinkage in the retina and veins, structural changes in retinal pigment epithelium, photoreceptor cells and veins, and causing intraretinal edema (9-11).

In this study, we aimed to evaluate the age, visual acuity and OCT findings of bilateral pseudophakic patients with ERM and to evaluate the relationship between these features.

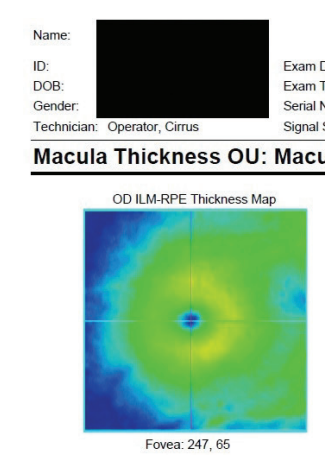

Fovea: 247,65
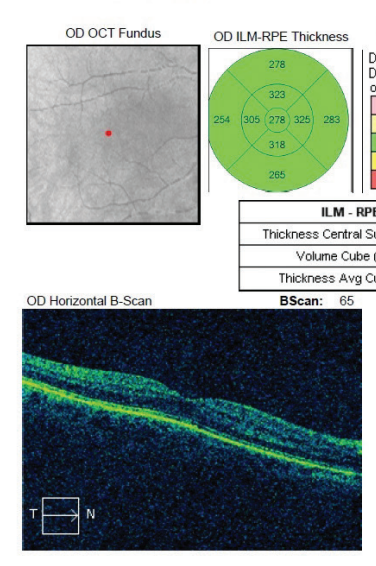
Comments

$$
\text { OD OS }
$$

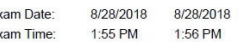$$
\begin{array}{lll}
\text { Exam Time: } & 1: 55 \mathrm{PM} & 1: 56 \mathrm{PM} \\
\text { Serial Number: } & 400-11000 & 400-11000
\end{array}
$$$$
\begin{array}{lll}
\text { Serial Number: } & 400-11000 & 400-11000 \\
\text { Signal Strength: } 3 / 10 & 4 / 10
\end{array}
$$

Macular Cube 512x128

OD O O OS
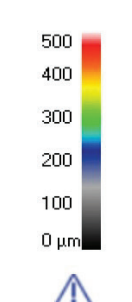

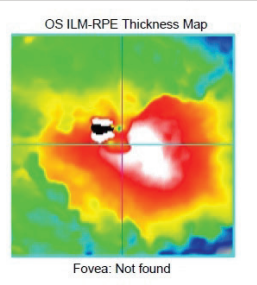

Fovea: Not found
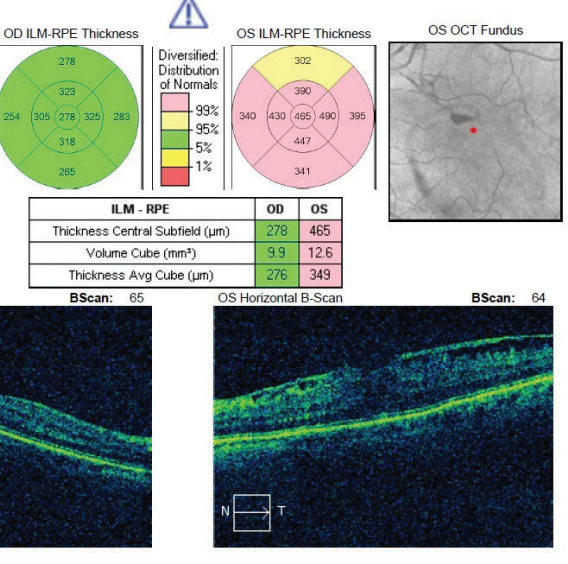

Image 1. OCT output of the patient with ERM in one eye.

OCT: optical coherence tomography, ERM: epiretinal membrane, OD: oculus dexter, OS: oculus sinister, ILM-PRE: internal limiting membrane-retinal pigment epithelium

\section{Methods}

In our study, patients who were admitted to our clinic between August 2017 and August 2018 and who had unilateral stage 2 ERM in their clinical examination were evaluated. Only bilateral pseudophakic patients were evaluated in order to evaluate the ERM-related visual acuity levels of the patients included in the study and to provide the retinal evaluation with OCT. Retinal imaging was performed with Cirrus HD-OCT (Carl Zeiss Meditec, Dublin, CA) to confirm the diagnosis of ERM and to evaluate macular volume and thickness of central macular and parafoveal quadrants (Image 1). The patients had no history of ocular surgery, except for cataract surgery. The patients with ophthalmologic disease history and detected pathology on ophthalmologic examination were not included in the study. Patients with hypertension, coronary artery disease and diabetes mellitus (DM) were excluded. Age, gender and visual acuity were recorded.

Among OCT findings, central macular thickness, mean retinal thickness in superior, nasal, inferior and temporal parafoveal quadrants (1-3 mm), distance between ILM and in retina pigment epithelium in the central macular region and macular volume within $6 \mathrm{~mm}$ horizontal and $6 \mathrm{~mm}$ vertical fovea-centered square area were recorded. OCT measurements and measurement classifications were performed according to the studies by Chan et al. (12) and Sabouri et al. (13).

Visual acuity levels according to the Snellen chart, intraocular pressures in $\mathrm{mmHg}$, detailed anterior segment and fundus examinations were recorded in all patients. The history of systemic and ocular disease of all patients was questioned. Patients with a history of systemic and ocular disease and patients with surgical history except for uncomplicated cataract surgery were excluded from the study. For statistical evaluation, the visual acuities recorded according to the Snellen chart were converted to the corresponding LogMAR values. In the statistical evaluation, the relationship between visual findings, OCT findings and visual acuity in eyes with and without ERM were evaluated.

İstanbul Training and Research Local Ethics Committee approval was obtained for this study (decision no: 882, date: 25.11.2016). The study was conducted in accordance with the Declaration of Helsinki. Written and oral consent were obtained from the patients included in the study and their data were evaluated within the scope of the study.

\section{Statistical Analysis}

Statistical analysis was performed using paired t-test in SPSS ver. 25 for Windows (SPSS Inc., Chicago, Illinois, USA) software. Descriptive statistics were given as number and percentage for categorical variables. Regarding correlation analysis, Pearson or Spearman correlation tests were used, where appropriate. $\mathrm{p}<0.05$ was considered statistically significant.

\section{Results}

The study included 82 eyes of 41 patients (19 women and 22 men) with a mean age of $71.4 \pm 6.4$ (range: 60 -86) years. The patients were pseudophakic and had ERM in one eye. Patients who had hypertension, 
coronary artery disease and DM were excluded. The visual acuities of the eyes with and without ERM were $0.35 \pm 0.24$ (range: 0.1-1.0) LogMAR and $0.0 \pm 0.1$ (range: 0.0-0.1) LogMAR, respectively.

When the findings of the eyes with and without ERM were compared, it was observed that there was a significant difference between two groups in terms of visual acuity, central macular thickness, and thickness of the superior, temporal, nasal and inferior parafoveal $(1-3 \mathrm{~mm})$ quadrants $(\mathrm{p}<0.05)$ (Table 1).
Regarding statistical relationship between visual acuity and central macular thickness (Figure 1), thickness of the superior (Figure 2), temporal (Figure 3), nasal (Figure 4) and inferior (Figure 5) parafoveal quadrants $(1-3 \mathrm{~mm})$, and macular volume (Figure 6) in the eyes with ERM, statistically significant negative correlation was found between visual acuity level and these parameters $(p=0.000, r=-0.689 ; p=0.004$ $r=-0.445 ; p=0.000, r=-0.577 ; p=0.004, r=-0.440 ; p=0.006, r=-0.422$; $p=0.001, r=-0.517$ ) (Table 2).

Table 1. Mean values of optical coherence tomography parameters between eyes with and without epiretinal membrane and statistical significance levels between them

\begin{tabular}{|l|l|l|}
\hline Parameter & Eyes with epiretinal membrane & Eyes with epiretinal membrane \\
\hline Central macula, $\mu \mathrm{m}$ & $355.4 \pm 75.4(234-554)$ & $250.4 \pm 34.2(183-317)$ \\
\hline Superior quadrant, $\mu \mathrm{m}$ & $371.4 \pm 60.3(287-558)$ & $323.8 \pm 30.7(260-375)$ \\
\hline Temporal quadrant, $\mu \mathrm{m}$ & $365.1 \pm 52.2(280-510)$ & $318.1 \pm 32.9(264-394)$ \\
\hline Inferior quadrant, $\mu \mathrm{m}$ & $365.6 \pm 44.3(307-494)$ & $322.1 \pm 26.9(267-371)$ \\
\hline Nasal quadrant, $\mu \mathrm{m}$ & $371 \pm 52.5(311-549)$ & $325.4 \pm 27.6(275-374)$ \\
\hline Cube volume $(\mathrm{mm} 3)$ & $11.3 \pm 1.1(9.7-15)$ & $9.9 \pm 0.7(8.1-11.5)$ \\
\hline
\end{tabular}

Table 2. The statistical assessment results of visual acuity and OCт findings in eyes with epiretinal membrane

\begin{tabular}{r|l|l|l|l|l|l|}
\hline & Central macula & Cube volume & Temporal & Superior & Nasal & Inferior \\
\hline BCVA & $p=0.000, r=-0.689$ & $p=0.001, r=-0.517$ & $p=0.000, r=-0.577$ & $p=0.004, r=-0.445$ & $p=0.004, r=-0.440$ & $p=0.006, r=-0.422$ \\
\hline
\end{tabular}

BCVA: best corrected visual acuity, OCT: optical coherence tomography

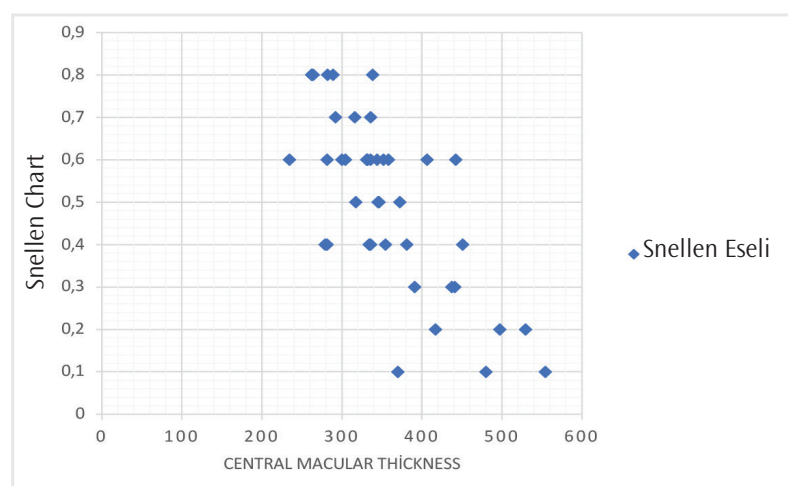

Figure 1. The distribution of visual acuity according to the Snellen chart and central macular thickness of the eyes with epiretinal membrane

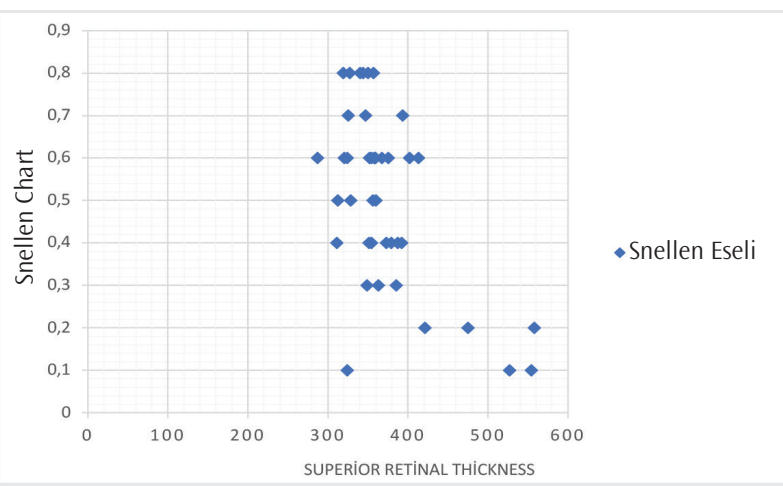

Figure 2. The distribution of visual acuity according to the Snellen chart and thickness of the superior parafoveal quadrant of the eyes with epiretinal membrane

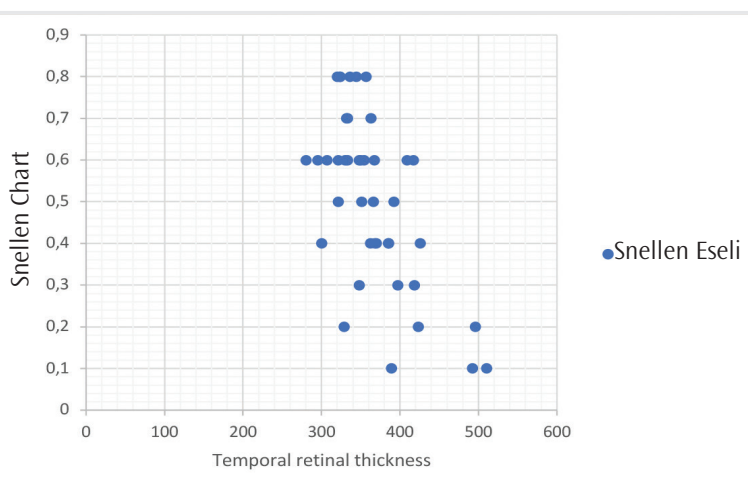

Figure 3. The distribution of visual acuity according to the Snellen chart and thickness of the temporal parafoveal quadrant of the eyes with epiretinal membrane

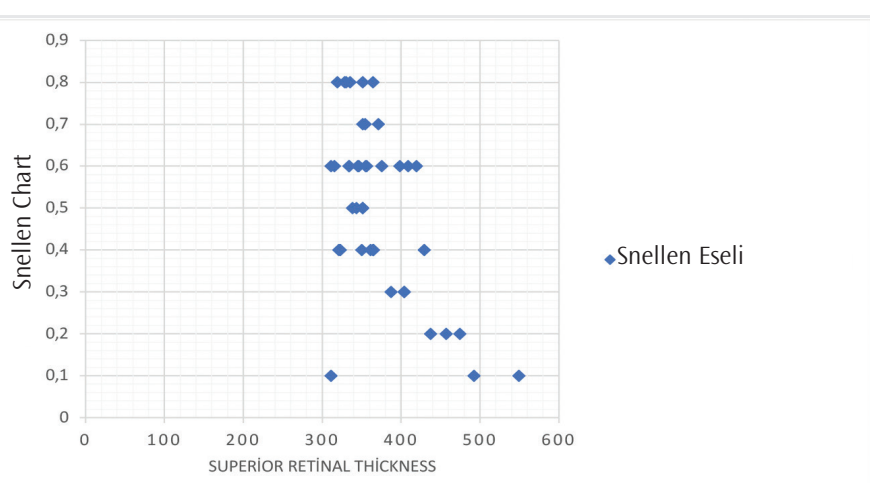

Figure 4. The distribution of visual acuity according to the Snellen chart and thickness of the nasal parafoveal quadrant of the eyes with epiretinal membrane 


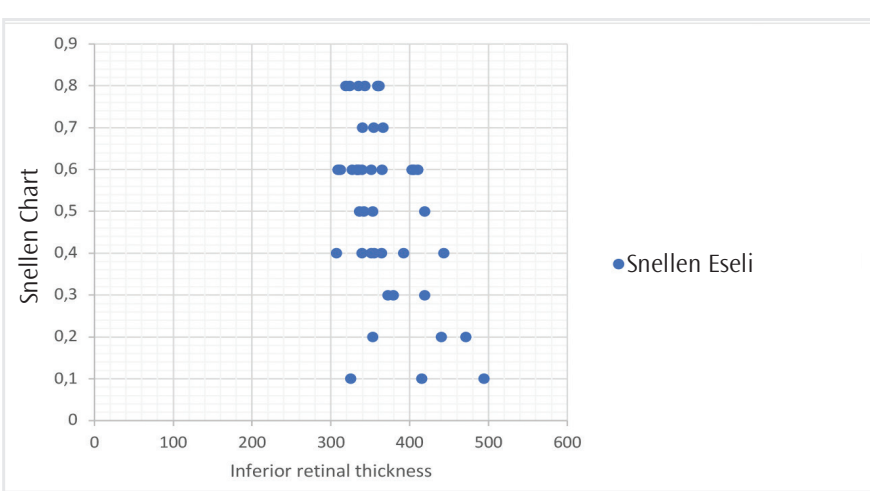

Figure 5. The distribution of visual acuity according to the Snellen chart and thickness of the inferior parafoveal quadrant of the eyes with epiretinal membrane

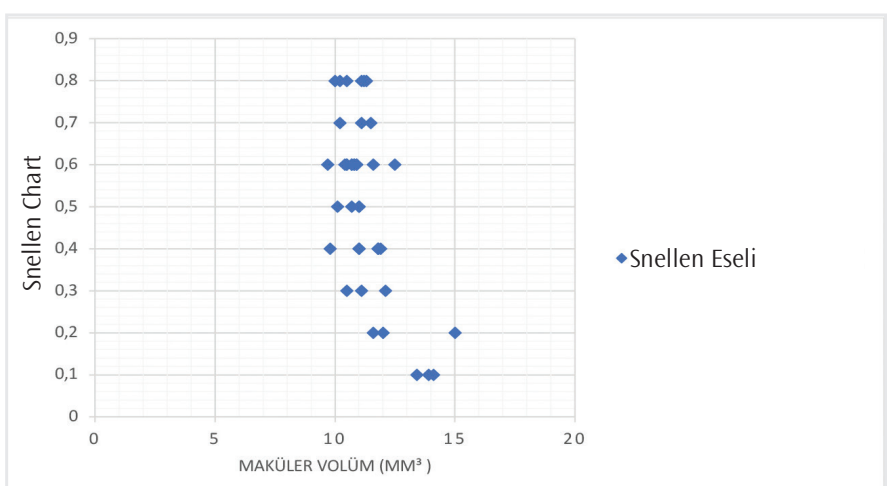

Figure 6. The distribution of visual acuity according to the Snellen chart and macular volume in optical coherence tomography of the eyes with epiretinal membrane

\section{Discussion}

Although the majority of the cases diagnosed as ERM were over 50 years of age, ERM was found in 2-6.4\% autopsy studies (14). FraserBell et al. (15) reported an ERM incidence of approximately 5.3\% in an epidemiological study. In an epidemiological study by Miyazaki et al. (16), the incidence of ERM in adults over 40 years of age was $4 \%$. All of the cases in our study were pseudophakic patients over the age of 60 years. Similar to other studies, ERM was associated with advanced age in our study. In a study by Klein et al. (17) evaluating the relationship between the disease and gender, they stated that the disease was more common in women than men. In our study, there was no statistically significant difference between men and women.

Stevenson et al. (1) reported that macular thickness was increased in patients with ERM. Chen et al. (18) showed that there was an increase in macular thickness in the ERM cases and that there was a correlation between the increase in macular thickness and visual acuity. Kumagai et al. (19) reported that macular thickness decreased and visual acuity improved after ERM surgery. In our study, central macular thickness, and thickness of the superior, temporal, nasal and inferior parafoveal quadrants $(1-3 \mathrm{~mm})$ in eyes with ERM were statistically higher than the same parameters in eyes without ERM. In addition, the mean visual acuity level in the eyes with ERM was statistically lower than in the eyes without eyes.

Pilli et al. (20) demonstrated the relationship between the increase in central macular thickness and the deterioration of macular morphology and decreased visual acuity. In their histological study, Paovic et al. (21) reported that visual acuity decreased in the central macular thickness increase due to ERM-related macular edema. Dawson et al. (22) reported that visual acuity decreased with central macular thickness increase and visual acuity increased in patients with decreased central macular thickness following macular surgery. The relationship between central macular thickness and visual acuity levels of the patients in our study was evaluated. In our study, there was also a statistically significant relationship between visual acuity level and central macular thickness. In our study, there was also a statistically significant relationship between visual acuity and central macular thickness, and thickness of the superior, temporal, nasal and inferior parafoveal quadrants (1-3 $\mathrm{mm}$ ) in eyes with ERM.

Reduction in visual acuity due to ERM and primary treatment of metamorphopsia were defined as pars plana vitrectomy (PPV) (23). In a study performed by Karabaş et al. (24), they defined the rate of visual acuity increase after PPV as 90\% in primary idiopathic ERM and $62.8 \%$ in secondary ERM cases. Tanawade et al. (25) reported in their study that visual acuity increased after PPV in $31.25 \%$ of cases, did not change in $31.25 \%$ and decreased in $37.5 \%$. Okomoto et al. (2) reported that metamorphopsia complaints could be resolved with PPV.

\section{Conclusion}

ERM is usually a disease related to advanced age. ERM is considered one of the vitreoretinal interface diseases. With or without intraretinal edema, the membrane causes visual symptoms as a result of an increase in macular thickness. The main treatment of the disease was defined as PPV. Examination of the vitreoretinal interface and evaluation of OCT in elderly patients presenting with low level of vision is very important in terms of overlooking disease. Surgical approach is a treatment option in patients with low visual acuity, micropsia, macropsy and metamorphopsia.

Ethics Committee Approval: İstanbul Training and Research Local Ethics Committee approval was obtained for this study (decision no: 882, date: 25.11.2016).

Informed Consent: Written and oral consent were obtained from the patients included in the study and their data were evaluated within the scope of the study.

Peer-review: Externally peer-reviewed.

Author Contributions: Concept - M.S.A.; Design - M.S.A.; Supervision - E.Ü.; Resources - E.Ü.; Materials - M.S.A.; Data Collection and/or Processing - M.S.A.; Analysis and/or Interpretation - M.S.A.; Literature Search - E.Ü.; Writing Manuscript - M.S.A.; Critical Review - E.Ü.

Conflict of Interest: The authors have no conflict of interest to declare.

Financial Disclosure: The authors declared that this study has received no financial support.

\section{References}

1. Stevenson W, Prospero Ponce CM, Agarwal DR, Gelman R, Christoforidis JB. Epiretinal membrane: optical coherence tomography-based diagnosis and classification. Clinical Ophthalmol 2016; 10: 527-34. 
2. Okamoto F, Okamoto Y, Hiraoka T, Oshika T. Effect of vitrectomy for epiretinal membrane on visual function and vision-related quality of life. Am J Ophthalmol 2009; 147: 869-74.

3. Inoue M, Kadonosono K. Macular diseases: epiretinal membrane. Dev Ophthalmol 2014; 54: 159-63.

4. Yazici AT, Alagöz N, Celik HU, Bozkurt E, Alagöz C, Cakir M, et al. Idiopathic and secondary epiretinal membranes: do they differ in terms of morphology? An optical coherence tomography-based study. Retina 2011; 31: 779-84.

5. Kampik A. Pathology of epiretinal membrane, idiopathic macular hole, and vitreomacular traction syndrome. Retina 2012; 32(Suppl 2): 194-8.

6. Stevenson W, Prospero Ponce CM, Agarwal DR, Gelman R, Christoforidis JB. Epiretinal membrane: optical coherence tomography-based diagnosis and classification. Clin Ophthalmol. 2016; 10: 527-34.

7. Legarreta JE, Gregori G, Knighton RW, Punjabi OS, Lalwani GA, Puliafito CA. Three-dimensional spectral-domain optical coherence tomography images of the retina in the presence of epiretinal membranes. Am J Ophthalmol 2008; 145: $1023-30$

8. Pournaras CJ, Donati G, Brazitikos PD, Kapetanios AD, Dereklis DL, Stangos NT. Macular Epiretinal Membranes. Semin Ophthalmol 2000; 15: 100-7.

9. Miguel Al, Legris A. Prognostic factors of epiretinal membranes: A systematic review. J Fr Ophtalmol 2017; 40: 61-79.

10. Konidaris V, Androudi S, Alexandridis A, Dastiridou A, Brazitikos P. Optical coherence tomography-guided classification of epiretinal membranes. Int Ophthalmol. 2015; 35: 495-501.

11. Altan Ç, Güngel H, Pınarcı E. Primer ve sekonder epiretinal membranların optik koherens tomografi bulgularının karşılaştırılması. Retina-Vitreus 2009; 17: 263-8.

12. Chan A, Duker JS, Ko TH, Fujimoto JG, Schuman JS. Normal macular thickness measurements in healthy eyes using stratus optical coherence tomography. Arch Ophthalmol 2006; 124 : 193-8.

13. Sabouri MR, Kazemnezhad E, Hafezi V. Assessment of macular thickness in healthy eyes using cirrus HD-OCT: A Cross-Sectional Study. Med Hypothesis Discov Innov Ophthalmol. 2016; 5: 104-11.

14. Sjarda R, Michels R. Macular pucker. In: Ryan S, editör. Retina. St. Louis: Mosby; 1994.p.2301-11.
15. Fraser-Bell S, Guzowski M, Rochtchina E, Wang J, Mitchell P. Five-year cumulative incidence and progression of epiretinal membranes: the Blue Mountains Eye Study. Ophthalmology 2003; 110: 34-40.

16. Miyazaki M, Nakamura $H$, Kubo $M$, Kiyohara $Y$, lida $M$, Ishibashi $T$, et al. Prevalence and risk factors for epiretinal membranes in a Japanese population: the Hisayama study. Graefe's Archive for clinical and experimental ophthalmology 2003; 241: 642-6.

17. Klein R, Klein BE, Wang Q, Moss SE. The epidemiology of epiretinal membranes. Trans Am Ophthalmol Soc 1994; 92: 403-30.

18. Chen L, Liu M, Xie AM, Liu Y. A study on change of macular retinal thickness and its relationship with vision before and after operation to idiopathic macular epiretinal membranes. Int J Clin Exp Med 2015; 8: 18571-80.

19. Kumagai K, Hangai M, Ogino N. Progressive thinning of regional macular thickness after epiretinal membrane surgery. Invest Ophthalmol Vis Sci 2015; 56: $7236-42$

20. Pilli S, Lim P, Zawadzki RJ, Choi SS, Werner JS, Park SS. Fourier-domain optical coherence tomography of eyes with idiopathic epiretinal membrane: correlation between macular morphology and visual function. Eye (Lond) 2011; 25: 775-83.

21. Paovic J, Paovic P, Paovic AS. Correlation between epiretinal membrane bridging, visual acuity and central macular thickness. J Cytol Histol. 2017; 8: $1-6$

22. Dawson SR, Shunmugam M, Williamson TH. Visual acuity outcomes following surgery for idiopathic epiretinal membrane: an analysis of data from 2001 to 2011. Eye (Lond) 2014; 28: 219-24.

23. Thompson JT. Vitrectomy for epiretinal membranes with good visual acuity. Trans Am Ophthalmol Soc 2004; 102: 97-103.

24. Karabaș L, Özkan B, Altıntaş Ö, Çağlar Y. Epiretinal membranlarda etyoloji ve vitreoretinal cerrahi sonuçlarımız. Ret-Vit 2006; 14: 193-6.

25. Tanawade RG, Tsierkezou L, Bindra MS, Patton NA, Jones NP. Visual outcomes of pars plana vitrectomy with epiretinal membrane peel in patients with uveitis. Retina 2015; 35: 736-41. 